\section{Sentinel phenotype for rubella embryopathy: time-space distribution in Brazil}

\author{
Fenótipo sentinela para embriopatia rubéolica: \\ distribuição em tempo e espaço no Brasil
}

\author{
${ }^{1}$ Departamento de Genética, \\ Universidade Federal do Rio \\ de Janeiro, Rio de Janeiro, \\ Brasil. \\ 2 Centro de Educação Médica \\ e Investigação Clinica, \\ Buenos Aires, Argentina. \\ ${ }^{3}$ Hospital Materno Infantil \\ Ramón Sardá, Buenos Aires, \\ Argentina. \\ ${ }^{4}$ Instituto Oswaldo Cruz, \\ Fundação Oswaldo Cruz. \\ Rio de Janeiro, Brasil. \\ Correspondence \\ I. M. Orioli \\ Centro de Ciências da Saúde, \\ Departamento de Genética, \\ Universidade Federal do \\ Rio de Janeiro. \\ Cidade Universitária, Bloco \\ A, sala 85, C.P. 68011, Rio de \\ Janeiro, RJ 21941-570, Brasil.
}

\section{Abstract}

The dyad comprising eye anomalies and congenital heart defects in the same newborn has been proposed as the best sentinel phenotype for the early detection of rubella embryopathy. Time-space birth prevalence distributions of the eye-heart dyad were described in 36 Brazilian hospitals from the Latin-American Collaborative Study of Congenital Anomalies - ECLAMC network, for the period 1994-2008. Seventy dyad cases observed among 554,531 births showed seasonal variation $\left(\chi^{2}=5.84 ; p<0.05\right)$, suggesting an environmental etiology, with an increase in cases in October-March and acrophase in December. The secular distribution of dyad prevalence rates was consistent with the distribution of rubella cases in Brazil, showing a decrease from 1994 to 2004, followed by an increase until 2008. Two geographic clusters were identified, one with high and the other with low dyad prevalence. In the high prevalence cluster, a secular increase was observed, starting in 1999, matching the rubella epidemic waves observed in Brazil in 1998-2000 and 2006.

Congenital Rubella Syndrome; Congenital Abnormalities; Clusters Analysis
Iêda Maria Orioli 1

Jorge S. López Camelo 2

Monica Rittler 3

Eduardo E. Castilla 4

\section{Introduction}

In 1941, Gregg identified the teratogenic effect of the rubella virus as the cause of a specific type of cataract, and in 1944 he recognized other ocular defects, deafness, and cardiopathies as the characteristic triad of congenital rubella syndrome (CRS) ${ }^{1}$. The most frequent ocular defects are cataract, microphthalmia, and retinopathy. Among the cardiopathies, the most frequent are patent ductus arteriosis, pulmonary arterial and valvular stenosis, and atrial septal defect. Other frequent defects include microcephaly, intrauterine growth restriction, and mental retardation.

A series of pathology studies on abortions of fetuses infected with the rubella virus, reviewed by Webster in 1998 1, showed that the majority of the structural and functional defects caused by the virus have a disruptive pattern, i.e., they result from the destruction of originally normal tissues or structures. Since the embryo or fetus infected by the rubella virus cannot eliminate the virus, transient problems may occur at birth, such as adenopathies, hepatosplenomegaly, meningoencephalitis, and thrombocytopenia. Studies in individuals over 50 years of age with a history of infection in utero showed late complications of congenital rubella, such as insulin-dependent diabetes, thyroid disorders, growth hormone deficiency, and progressive pan-encephalitis 2.

In 1985, South \& Sever 3 defined the CRS as any combination of findings resulting from ges- 
tational rubella. This definition is now used indistinctly to include embryonic developmental defects induced by the viral infection in the first trimester of embryonic life, as well as persistent infection at birth. However, the term rubella embryopathy refers only to the structural and permanent congenital defects that are caused by the virus, generally acquired during the infection, generally acquired during the first trimester of pregnancy 4 .

From 1992 to 2000, Brazil implemented gradual immunization against measles, mumps, and rubella with the triple viral vaccine (MMR) in children 1-11 years of age, postpartum and postabortion women and in specific campaigns. In 2001 and 2002, a national immunization campaign was launched, first in 13 States and later in 11, for all women 15-29 years of age. With the recrudescence of CRS, a new national campaign was held in 2008, aimed at eradicating the rubella virus from the country 5,6 .

To help evaluate the results of immunization campaigns against the rubella virus, a sentinel phenotype for rubella embryopathy was proposed in 2004, defined as the joint presence of congenital eye anomalies and heart defects in the same patient. A previous study 4 using material from the ECLAMC database (Latin American Collaborative Study of Congenital Malformations) showed a high proportion of newborns affected by this eye-heart dyad in the sub-sample of Brazilian hospitals as compared to other Latin American countries.

The aim of the current study was to describe the spatial and temporal (seasonal and secular) distribution of the eye-heart dyad as a sentinel phenotype for rubella embryopathy and to compare it with rubella epidemiology in Brazil.

\section{Material and methods}

The ECLAMC research project was launched in 1967, operating through a network of maternity hospitals in ten South American countries. Participation is voluntary, complying with operational guidelines and periodically assessing the minimum data quality criteria 7 .

Material for this study was obtained from the ECLAMC database. A total of 2,418 infants with congenital cardiopathies, 260 congenital ocular anomalies, and 70 infants with both types of malformations in the same neonate (the "eye-heart dyad") were identified among 554,531 births examined in 36 consecutive series, corresponding to 36 maternity facilities participating in the study from 1994 to 2008. These 36 observation sites are located in 19 cit- ies (Salvador, Bahia State; Belo Horizonte, Governador Valadares, and Poço de Caldas, Minas Gerais State; João Pessoa, Paraíba State; Rio de Janeiro, Rio de Janeiro State; Montenegro, Passo Fundo, Pelotas, and Porto Alegre, Rio Grande do Sul State; Florianópolis and Joinville, Santa Catarina State; Amparo, Caçapava, Campinas, Guapiara, Ribeirão Preto, São Paulo, and Valinhos, São Paulo State), that is, in 7 States located in 3 major geographic regions of Brazil: the Northeast, Southeast, and South.

All consecutive liveborn and stillborn infants weighing $500 \mathrm{~g}$ or more were systematically examined according to the ECLAMC protocol, published elsewhere 7 .

Cases of rubella embryopathy were defined as those presenting the eye-heart dyad, alone or in association with other malformations, without any type of exclusions such as known syndromes, chromosomal anomalies, etc. In other words, the eye-heart dyad was defined operationally as the sentinel phenotype for rubella embryopathy.

The following ocular malformations (according to the International Classification of Diseases, 10th Revision) were considered in this study, since they are obvious in the neonatal period: coloboma of eyelid (Q10.3), anophthalmia (Q11.1), microphthalmia (Q11.2), cataract (Q12.0), coloboma of iris (Q13.0), aniridia (Q13.1), congenital corneal opacity (Q13.3), congenital malformation of choroid (Q14.3), and buphthalmus glaucoma of the newborn (Q15.0).

All the types of structural congenital cardiopathies and anomalies of major vessels were included (Q2-), except for benign and innocent cardiac murmurs (R01.0), patent ductus arteriosus (Q25.0) in low birth weight newborns, and congenital malformations of the peripheral vascular system (Q27.-).

To analyze the secular trend, a Poisson regression was used, incorporating the linear and quadratic terms of the time variable into the model. Two approaches were performed in the secular trend analysis, one using total births as the denominator and the other using total cardiopathies. The latter was intended to correct the increasing linear trend in cardiopathies due to the improvement in diagnostic techniques, especially prenatal and postnatal echocardiography.

Adjustment for seasonal temporal variation used the Walter \& Elwood test 8 . The method tests the null hypothesis with a sine trigonometric function using the chi-square test with 2 degrees of freedom. If the null hypothesis is rejected, a chi-square test for goodness-of-fit with 11 degrees of freedom is performed to prove whether the observed data fit those expected according to the model 8 . 
A spatial cluster analysis of cases of the eye-heart dyad during the study period (19942008) was performed according to the Kulldorff \& Nagarwalla method ${ }^{9}$, using SaTScan v. 7.0.3 (http:\\www.satscan.org, USA). Each hospital's geographic coordinates were determined, and without prior definition of regions, the program grouped hospitals with similar prevalence rates for the eye-heart dyad.

A limitation for the formation of a cluster was that its total births could not exceed $20 \%$ of the total birth sample. In other words, for a total sample of 554,531 births, no cluster could have more than 110,906 births. Having identified a cluster, the temporal distribution of cases was analyzed with Poisson regression in arbitrary 5-year intervals within each cluster and for the rest of the sample, i.e., for hospitals whose rates did not differ from the total sample.

Although the ECLAMC database includes data since 1967, the study was limited to the last 15 years in order to minimize the sample's heterogeneity, due to demographic, health, and diagnostic modifications over long time period. On the other hand, the period could not be too short, due to the low expected prevalence of the eye-heart dyad.

The search in the ECLAMC database was submitted for review and approval by the Institutional Review Board of the Fernandes Figueira Institute, Oswaldo Cruz Foundation, Rio de Janeiro, Brazil.

\section{Results}

Table 1 shows the number of cases of eye-heart dyad, congenital cardiopathies, ophthalmopathies, and total births for each of the 36 hospitals analyzed for 1994-2008. Only 17 hospitals reported cases of eye-heart dyad.

The secular trend for 1994-2008 showed a decrease in prevalence rates for eye-heart dyad from 1994 to 2004, with a subsequent increase beginning in 2005, both for cardiopathies as the denominator $(\mathrm{b} 1$ linear $=-0.032, \mathrm{Z}=-1.22$, $\mathrm{P}=0.222 ; \mathrm{b} 2$ quadratic $=0.012, \mathrm{Z}=1.99, \mathrm{P}<$ $0.05) ; \chi^{2}{ }_{12}$ goodness-of-fit $=7.54, \mathrm{P}=0.820$, and for births as the denominator (b1 linear $=-0.013$, $\mathrm{Z}=-0.52, \mathrm{P}=0.600 ; \mathrm{b} 2$ quadratic $=0.012, \mathrm{Z}=1.98$, $\mathrm{P}<0.05) ; \chi^{2}{ }_{12}$ goodness-of-fit $=8.58, \mathrm{P}=0.738$ (Table 2 and Figures 1 and 2). Both models fit the observed cases.

The eye-heart dyad showed a significant seasonal variation $\left(\chi^{2}{ }_{2}=5.84 ; \mathrm{P}<0.05\right)$, with an increase in cases in the October-March semester and acrophase in December. The data fit the seasonality model $\left(\chi^{2}{ }_{11}=11.54, \mathrm{P}=0.399\right)$.
Two clusters were identified, one with high and the other with low prevalence for the eyeheart dyad (Table 3). The high prevalence cluster includes hospitals in Rio de Janeiro, Caçapava, and Belo Horizonte, with 3.68 cases of the dyad per 10,000 births and a $95 \%$ confidence interval (95\%CI) of 2.40-5.39. The low prevalence cluster consists of one hospital each in the cities of Governador Valadares, Salvador, and João Pessoa, or a rate of $0.12 / 10,000$ (95\%CI: $0.00-0.70)$. The other hospitals in the study showed a homogeneous prevalence of 1.06/10,000 (95\%CI: 0.79 1.43). Within the high prevalence cluster, there was a significant secular increase beginning in 1999 (b1 linear: 0.509, $\mathrm{Z}=2.05, \mathrm{P}<0.05$ ), not observed in the low prevalence cluster (not possible to test, because it presented zero cases in the two periods) or in the rest of the hospitals included in the study (b1 linear: $-0.137, \mathrm{Z}=-0.72, \mathrm{P}=0.469$ ).

\section{Discussion}

Ideally, the use of the eye-heart dyad as the sentinel phenotype for rubella embryopathy would require clinical and immunological proof of each of the 70 cases, thereby providing a quantification of the degree of the dyad's specificity and sensitivity. However, a previous study of material from ECLAMC 4, based on cases of rubella embryopathy, showed that the eye-heart dyad represented the best sentinel phenotype, combining a sensitivity of $34.9 \%$ with a high specificity (98.9\%). Thus, the temporal and spatial analyses of eye-heart dyad prevalence in the current study were also compared to information on rubella epidemiology in Brazil, to determine whether in practice the analysis of eye-heart dyad might help monitor rubella embryopathy.

Births with the eye-heart dyad showed a significant seasonal variation, with a peak incidence in December. Given that the majority of the sample is southern sub-tropical, this acrophase corresponds to summer in the region. For a term gestation, this corresponds to conception in March, or autumn. This finding is consistent with a study in the State of Pernambuco for 20002004, published by Oliveira et al. in 2008 10, showing a peak rubella prevalence in infants born in the month of November. Seasonal variation in prevalence rates for the eye-heart dyad is probably the most significant finding in this study, because it points to an environmental cause 8 , namely the rubella virus.

The secular trend in the eye-heart dyad in the 15-year study period showed a decrease from 1994 to 2004 and a subsequent increase until 2008. This result was the same both when ana- 
Table 1

Cases of congenital eye-heart dyad, cardiopathies, and ophthalmopaties in 36 hospitals in Brazil, 1994-2008.

\begin{tabular}{|c|c|c|c|c|c|c|c|}
\hline Region & State & City & Hospital & Dyads (n) & Cardiopathies (n) & Ophthalmopathies (n) & Births (n) \\
\hline NE & BA & Salvador & A47 & 0 & 10 & 6 & 17,075 \\
\hline NE & PB & João Pessoa & A56 & 1 & 223 & 42 & 51,329 \\
\hline SE & MG & Belo Horizonte & A39 & 19 & 440 & 41 & 38,763 \\
\hline SE & MG & Belo Horizonte & A60 & 2 & 38 & 6 & 10,745 \\
\hline SE & MG & Belo Horizonte & A62 & 0 & 29 & 3 & 8,575 \\
\hline SE & MG & Governador Valadares & A19 & 0 & 13 & 1 & 10,671 \\
\hline SE & MG & Poços de Caldas & A24 & 0 & 7 & 0 & 10,456 \\
\hline SE & RJ & Rio de Janeiro & A05 & 5 & 96 & 12 & 1,733 \\
\hline SE & RJ & Rio de Janeiro & A35 & 0 & 9 & 2 & 6,406 \\
\hline SE & RJ & Rio de Janeiro & A61 & 0 & 1 & 2 & 726 \\
\hline SE & SP & Amparo & A29 & 0 & 2 & 0 & 8,015 \\
\hline SE & $\mathrm{SP}$ & Caçapava & $\mathrm{A} 37$ & 0 & 2 & 0 & 3,240 \\
\hline SE & SP & Caçapava & A38 & 0 & 0 & 0 & 454 \\
\hline SE & $\mathrm{SP}$ & Campinas & A33 & 11 & 333 & 52 & 45,788 \\
\hline SE & SP & Campinas & A49 & 1 & 110 & 3 & 7,223 \\
\hline SE & $\mathrm{SP}$ & Guapiara & A58 & 0 & 0 & 0 & 397 \\
\hline SE & $\mathrm{SP}$ & Ribeirão Preto & A07 & 3 & 46 & 0 & 5,429 \\
\hline SE & $\mathrm{SP}$ & São Paulo & $\mathrm{A} 02$ & 0 & 5 & 1 & 2,212 \\
\hline SE & $\mathrm{SP}$ & São Paulo & A10 & 3 & 166 & 4 & 23,280 \\
\hline SE & SP & São Paulo & A28 & 3 & 59 & 1 & 13,891 \\
\hline SE & $\mathrm{SP}$ & São Paulo & A46 & 2 & 46 & 10 & 6,900 \\
\hline SE & SP & Valinhos & A06 & 1 & 2 & 1 & 6,565 \\
\hline $\mathrm{S}$ & RS & Montenegro & A20 & 0 & 2 & 0 & 4,754 \\
\hline $\mathrm{S}$ & RS & Montenegro & A57 & 0 & 2 & 0 & 969 \\
\hline $\mathrm{S}$ & RS & Passo Fundo & A44 & 0 & 5 & 3 & 6,074 \\
\hline S & RS & Pelotas & A45 & 0 & 2 & 3 & 7,437 \\
\hline S & RS & Pelotas & A52 & 0 & 2 & 0 & 3,201 \\
\hline $\mathrm{S}$ & RS & Pelotas & A53 & 0 & 2 & 0 & 2,611 \\
\hline $\mathrm{S}$ & RS & Pelotas & A54 & 0 & 0 & 0 & 139 \\
\hline $\mathrm{S}$ & RS & Pelotas & A55 & 0 & 0 & 0 & 469 \\
\hline $\mathrm{S}$ & RS & Porto Alegre & A43 & 2 & 94 & 10 & 52,811 \\
\hline S & RS & Porto Alegre & A25 & 8 & 169 & 19 & 60,819 \\
\hline $\mathrm{S}$ & RS & Porto Alegre & A59 & 1 & 7 & 2 & 6,088 \\
\hline $\mathrm{S}$ & $\mathrm{SC}$ & Florianópolis & $\mathrm{A} 04$ & 4 & 301 & 22 & 60,894 \\
\hline $\mathrm{S}$ & $\mathrm{SC}$ & Florianópolis & A50 & 1 & 99 & 7 & 16,896 \\
\hline $\mathrm{S}$ & SC & Joinville & A51 & 3 & 96 & 7 & 51,496 \\
\hline Total & & & - & 70 & 2,418 & 260 & 554,531 \\
\hline
\end{tabular}

NE: Northeast; S: South; SE: South; BA: Bahia; MG: Minas Gerais; PB: Paraíba; RJ: Rio de Janeiro; RS: Rio Grande do Sul; SC: Santa Catarina; SP: São Paulo.

lyzing the prevalence of eye-heart dyad among total births and among congenital cardiopathies. In 2003, the Pan-American Health Organization (PAHO) proposed a strategy to eliminate rubella and CRS from the Americas by 2010, and after apparently successful immunization campaigns, the number of rubella cases in the Americas showed a 98\% reduction in 1998-2006. However, 2007 witnessed outbreaks in Brazil, Chile, and Ar- gentina 11, especially in the Southeast and South of Brazil. The distribution of confirmed rubella cases per epidemiological week in Brazil 5, from 2000 to 2007, also showed two peaks, one that tapered off from 2000 to 2004 and another that increased from 2006 to 2007. Thus the secular temporal distribution in prevalence rates for eyeheart dyad in the current study is consistent with the observed distribution of rubella cases. 
Cases of congenital eye-heart dyad, cardiopathies, and ophthalmopathies and frequency of dyads, by year.

\begin{tabular}{|c|c|c|c|c|c|c|}
\hline \multirow[t]{2}{*}{ Year } & \multirow[t]{2}{*}{ Births (n) } & \multirow[t]{2}{*}{ Cardiopathies (n) } & \multirow[t]{2}{*}{ Ophthalmopathies (n) } & \multicolumn{3}{|c|}{ Eye-heart dyads } \\
\hline & & & & $\mathrm{n}$ & Per 10,000 births & Per 100 cardiopathies \\
\hline 1994 & 36,689 & 110 & 14 & 6 & 1.64 & 5.45 \\
\hline 1995 & 33,000 & 108 & 17 & 3 & 0.91 & 2.78 \\
\hline 1996 & 32,216 & 120 & 8 & 5 & 1.55 & 4.17 \\
\hline 1997 & 30,723 & 105 & 12 & 5 & 1.63 & 4.76 \\
\hline 1998 & 31,346 & 106 & 22 & 3 & 0.96 & 2.83 \\
\hline 1999 & 38,520 & 133 & 11 & 3 & 0.78 & 2.26 \\
\hline 2000 & 40,104 & 170 & 11 & 7 & 1.75 & 4.12 \\
\hline 2001 & 38,742 & 186 & 12 & 2 & 0.52 & 1.08 \\
\hline 2002 & 40,231 & 221 & 14 & 3 & 0.75 & 1.36 \\
\hline 2003 & 42,061 & 204 & 20 & 6 & 1.43 & 2.94 \\
\hline 2004 & 42,581 & 171 & 16 & 3 & 0.70 & 1.75 \\
\hline 2005 & 37,518 & 177 & 21 & 4 & 1.07 & 2.26 \\
\hline 2006 & 38,298 & 159 & 18 & 7 & 1.83 & 4.40 \\
\hline 2007 & 38,281 & 229 & 33 & 5 & 1.31 & 2.18 \\
\hline 2008 & 34,221 & 219 & 31 & 8 & 2.34 & 3.65 \\
\hline Total & 554,531 & 2,418 & 260 & 70 & 1.26 & 2.89 \\
\hline
\end{tabular}

Contrary to the initial assumption, the similar results obtained with the two analytical approaches of the secular trends in prevalence rates for eye-heart dyad indicate that the known increase (also secular) in the capacity for perinatal detection of congenital cardiopathies using ultrasound and echocardiography 12,13 had little effect on the secular trends in prevalence rates for the eye-heart dyad.

Brazil's continental size leads one to expect a wide heterogeneity in rubella epidemiology, both in the implementation of health measures for its control and in the occurrence of outbreaks, just like any other population characteristic. This scenario speaks for the use of a method for analyzing the sample by subdividing it without preconceived definitions of geographic regions. Cluster analysis using the Kulldorff \& Nagarwalla method ${ }^{9}$ had already been applied successfully to the ECLAMC material to study the epidemiology of oral clefts in South America (Poletta et al., 1997 14).

This analysis of prevalence rates for the eyeheart dyad as a proportion of total births grouped the observation sites (hospitals) into three prevalence categories: high (3.68; 95\%CI: 2.40-5.29), low (0.12; 95\%CI: $0.00-0.70)$, and expected, or the rest (1.06; 95\%CI: 0.79-1.43).

The high prevalence cluster includes 8 hospitals from the cities of Rio de Janeiro, Caçapava, and Belo Horizonte, all in Southeast Brazil. That two hospitals from Caçapava, with no reported cases with the dyad, were part of this high prevalence cluster, could be due to the small number of births in these hospitals, resulting in a very wide confidence interval and thus in the nonexclusion of these hospitals from the geographic cluster formed by the hospitals from Rio de Janeiro and Belo Horizonte. Meanwhile, since some maternity facilities are reference centers for pregnancies with congenital anomalies, part of the heterogeneity in the prevalence of eyeheart dyad is expected, as with malformations in general.

The low prevalence cluster includes 3 maternity facilities from Governador Valadares, Salvador, and João Pessoa, and even though the first city belongs administratively to the Southeast of Brazil, it was possible to combine it with the other two, located in the Northeast.

Comparison of the time periods within each cluster identified by the prevalence rate for eyeheart dyad at birth showed a secular increase in the high prevalence series beginning in 1999. The low prevalence region is not informative, since it showed only one case in nearly 80,000 births. Excluding these two series with extreme prevalence rates, in the rest of Brazil, with approximately 400,000 births examined, no secular trend was observed. 
Figure 1

Secular trend for 1994-2008 in the prevalence of congenital eye-heart dyad per 10,000 births.

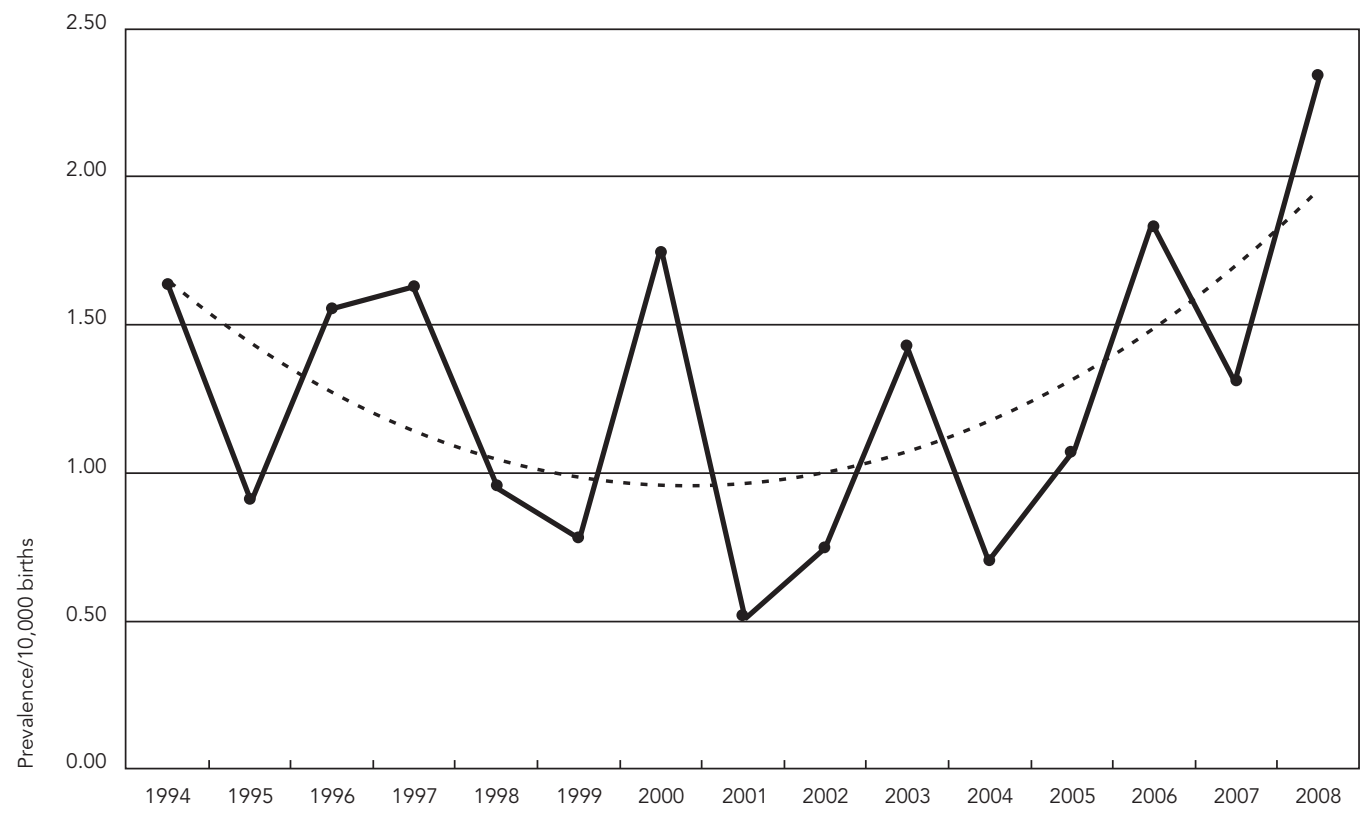

Observed values

Expected values according to Poisson regression model

Figure 2

Secular trend for 1994-2008 in the prevalence of congenital eye-heart dyad per 100 congenital cardiopathies.

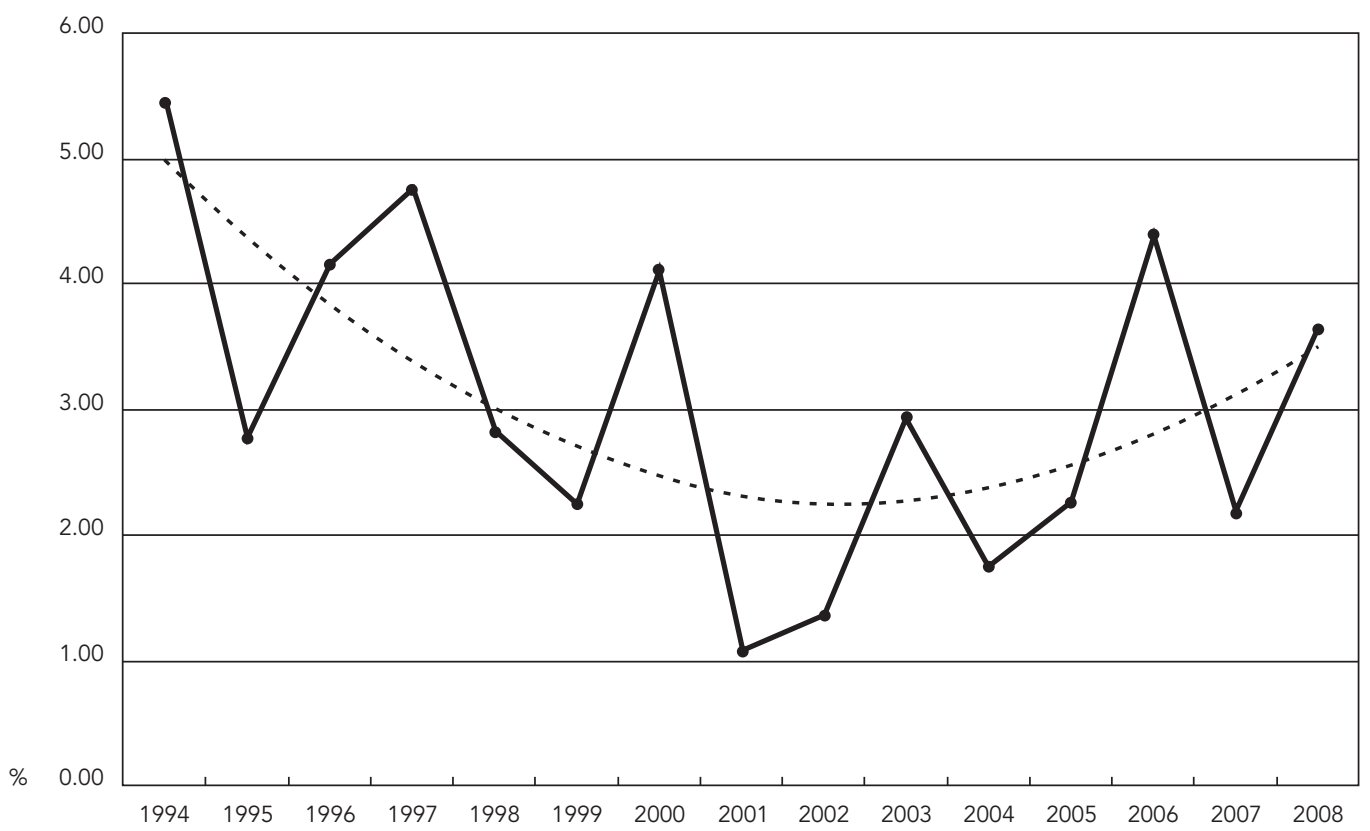


Time-space clusters of congenital eye-heart dyads, 1994-2008.

\begin{tabular}{|c|c|c|c|c|c|c|c|}
\hline \multirow[t]{2}{*}{ Region } & \multirow[t]{2}{*}{ City (UF) } & \multirow[t]{2}{*}{ Hospital } & \multirow[t]{2}{*}{ Period } & \multirow[t]{2}{*}{ Births } & \multicolumn{3}{|c|}{ Dyads } \\
\hline & & & & & $\mathrm{n}$ & Rate & $95 \% \mathrm{Cl}$ \\
\hline \multirow[t]{4}{*}{ SE } & Rio de Janeiro (RJ)/Caçapava (SP)/Belo & $\mathrm{A} 05, \mathrm{~A} 35, \mathrm{~A} 62, \mathrm{~A} 37, \mathrm{~A} 38$ & 1994-1998 & 19,074 & 3 & 1.57 & $3.24-4.60$ \\
\hline & Horizonte (MG) & A39, A60, A61 & 1999-2003 & 14,843 & 7 & 4.72 & $1.90-9.71$ \\
\hline & & & 2004-2008 & 36,725 & 16 & 4.38 & $2.49-7.07$ \\
\hline & & & Sub-total & 70,642 & 26 & 3.68 & $2.40-5.39$ \\
\hline \multirow[t]{8}{*}{ NE/SE } & Governador Valadares (MG)/Salvador (BA)/ & A19, A47, A56 & 1994-1998 & 1,633 & 0 & 0.00 & $0.00-2.25$ \\
\hline & João Pessoa (PB) & & 1999-2003 & 27,848 & 1 & 0.36 & $0.00-2.00$ \\
\hline & & & 2004-2008 & 49,594 & 0 & 0.00 & $0.00-0.74$ \\
\hline & & & Sub-total & 79,075 & 1 & 0.13 & $0.00-0.71$ \\
\hline & Rest of Brazil & 25 other hospitals & 1994-1998 & 143,267 & 19 & 1.33 & $0.80-2.07$ \\
\hline & & & 1999-2003 & 152,426 & 13 & 0.85 & $0.46-1.86$ \\
\hline & & & 2004-2008 & 109,121 & 11 & 1.00 & $0.50-1.80$ \\
\hline & & & Sub-total & 404,814 & 43 & 1.06 & $0.79-1.43$ \\
\hline Total & & & & 554,531 & 70 & 1.26 & $0.98-1.59$ \\
\hline
\end{tabular}

Note: rate/10,000 births.

NE: Northeast; S: South; SE: Southeast; BA: Bahia; MG: Minas Gerais; PB: Paraíba; RJ: Rio de Janeiro; RS: Rio Grande do Sul; SC: Santa Catarina; SP: São Paulo.

Although the association may be spurious and may not reflect a cause-and-effect relationship, the high prevalence of the rubella sentinel dyad in the Southeast with an upward trend starting in 1999 corresponds to the series of reported rubella outbreaks in Brazil in 1998-2000 6 and in 200611.

Neither control measures like immunization campaigns nor rubella outbreaks in Brazil have been well-demarcated in time or space. Thus, a clear, well-defined correlation with the occurrence of eye-heart dyad was not to be expected. It is possible that a study similar to the one presented here, with material limited to a single municipality, would result in more solid conclusions; however, the low prevalence of eyeheart dyad, as proposed originally ${ }^{4}$, in the order of 1/10,000 births, would require many large municipalities with more than 50,000 births per year and for accumulated periods of 10 years or more. Such approaches should be possible beginning in 2016, with data from the Life Birth Certificates recorded in the Information System on Live Births (SINASC), in São Paulo, Rio de Janeiro, and some other municipalities.

The main limitation to this study was that it did not use a population-based sample, nor did it have sufficient size to be representative of a population, so that its results may be subject to numerous biases and epidemiological confounding factors. However, the lack of sources of information on the congenital anomalies used for this sentinel phenotype of rubella embryopathy justifies tolerating the principal limitation of the material used here. SINASC, through data on congenital malformations in field 34 of the live birth certificate, in operation since 1999, does not allow identification of the eye-heart dyad proposed by the authors in $2004{ }^{4}$ and applied in this study, since it was not possible to record more than one malformation per live birth until 2006 15. The current study's robustness lies precisely in the fact that the ECLAMC database is hospital-based, with controlled quality and a detailed description of all the newborns that are examined (both live births and stillbirths) 7 . However, even with less detailed information such as that coded by the ICD-10 and grouped at the three-digit level, it would be possible to identify both components of the proposed eye-heart dyad, using codes Q20 to Q26 for cardiopathies and Q10 to Q15 for ophthalmopathies. Rubella has still not been eradicated in many parts of the world, and the congenital eye-heart dyad could serve as an easy-to-use, low-cost, and powerful tool for epidemiological surveillance of rubella embryopathy in the immediate future. 


\section{Resumo}

A díade óculo-cardíaca havia sido proposta como o melhor fenótipo sentinela para detecção precoce da embriopatia rubéolica. Descrevem-se as distribuições têmporo-espaciais das prevalências ao nascimento dessa díade com material do Estudo Colaborativo Latino Americano de Malformações Congênitas (ECLAMC) em 36 hospitais brasileiros no período 1994-2008. Os 70 casos em 554.531 nascimentos mostraram uma variação sazonal significativa $\left(\chi^{2}=5,84 ; p<0,05\right)$, o que sugere uma etiologia ambiental, com um aumento de casos de outubro a março com acrofase em dezembro. A variação secular das prevalências da díade foi compatível com o padrão observado para a distribuição da rubéola no país, com diminuição entre 1994-2004, e ulterior aumento até 2008. Identificaram-se dois conglomerados de alta e de baixa prevalência para a díade. Dentro do conglomerado de alta prevalência, observou-se significativo acréscimo secular a partir do ano 1999, não verificado no conglomerado de baixa prevalência, nem no resto dos hospitais em estudo, compatível com a série de surtos epidêmicos registrados para a infecção rubeólica no Brasil em 1998-2000 e em 2006.

Síndrome da Rubéola Congênita; Anormalidades Congênitas; Análise por Conglomerados

\section{Contributors}

All the authors contributed to the conception and project or data analysis and interpretation, writing of the article or relevant critique of the intellectual content, and approval of the final version for publication.

\section{Acknowledgments}

Funding sources: Brazilian National Research Council (CNPq), grant no. 573993/2008-4; INCTP-INAGEMP; Ministry of Science and Technology/CNPq, Brazil, grants no. 476978/2008-4 and 306750/2009-0; Rio de Janeiro State Research Foundation, grants no. E26/171.492/2006 and E-26/102.748/2008; and Argentine National Council for Scientific and Technical Research (CONICET PEI) grant no. 6475-2007-2008.

\section{References}

1. Webster W. Teratogen update: congenital rubella. Teratology 1998; 58:13-23.

2. Forrest JM, Turnbull FM, Sholler GF, Hawker RE, Martin FJ, Doran TT, et al. Gregg's congenital rubella patients 60 years later. Med J Aust 2002; 177:664-7.

3. South MA, Sever JL. Teratogen update: the congenital rubella syndrome. Teratology 1985; 31: 297-307.

4. Rittler M, López-Camelo J, Castilla EE. Monitoring congenital rubella embryopathy. Birth Defects Res A Clin Mol Teratol 2004; 70:939-43.

5. Departamento de Vigilância Epidemiológica, Secretaria de Vigilância em Saúde, Ministério da Saúde. Brasil livre da rubéola: campanha nacional de vacinação para eliminação da rubéola, Brasil, 2008: relatório. Brasília: Ministério da Saúde; 2009. (Série B, Textos Básicos de Saúde).

6. Castillo-Solórzano C, Carrasco P, Tambini G, Reef $\mathrm{S}$, Brana M, Quadros CA. New horizons in the control of rubella and prevention of congenital rubella syndrome in the Americas. J Infect Dis 2003; 187 Suppl 1:S146-52.

7. Castilla EE, Orioli IM. ECLAMC: The Latin American Collaborative Study of Congenital Malformations. Community Genet 2004; 7:76-94.

8. Walter SD, Elwood JM. A test for seasonality of events with a variable population at risk. Br J Prev Soc Med 1975; 29:18-21.

9. Kulldorff M, Nagarwalla N. Spatial disease clusters: detection and inference. Stat Med 1995; 14: 799-810.

10. Oliveira MJC, Cordeiro MT, Costa FM, Murakami MG, Silva AMS, Travassos RC, et al. Freqüência de sarampo, rubéola, dengue e eritema infeccioso entre casos suspeitos de sarampo e rubéola no estado de Pernambuco, no período de 2001 a 2004. Rev Soc Bras Med Trop 2008; 41:338-44.

11. Progress toward elimination of rubella and congenital rubella syndrome: the Americas, 2003-2008. MMWR Morb Mortal Wkly Rep 2008; 57:1176-9.

12. Botto LD, Correa A, Erickson JD. Racial and temporal variations in the prevalence of heart defects. Pediatrics 2001; 107:E32.

13. Chung ML, Lee BS, Kim EA, Kim KS, Pi SY, Oh YM, et al. Impact of fetal echocardiography on trends in disease patterns and outcomes of congenital heart disease in a neonatal intensive care unit. Neonatology 2009; 98:41-6.

14. Poletta FA, Castilla EE, Orioli IM, López-Camelo JS. Spatial analysis on the occurrence of oral clefts in South America. Am J Med Genet 2007; 143A: 3216-27.

15. Luquetti DV, Koifman RJ. Quality of reporting on birth defects in birth certificates: case study from a Brazilian reference hospital. Cad Saúde Pública 2009; 25:1721-31.

Submitted on $26 / \mathrm{Feb} / 2010$

Final version resubmitted on 25/Jan/2011

Approved on 26/Apr/2011 